\title{
Peningkatan Kompetensi UMKM Melalui Pelatihan Pencatatan Dan Pelaporan Keuangan
}

\author{
Rio Monoarfa ${ }^{1}$, Tri Handayani Amaliah ${ }^{2}$ \\ ${ }^{1}$ Jurusan Akuntansi, Fakultas Ekonomi, Universitas Negeri Gorontalo, Jl. Jend. Sudirman \\ No. 6 Kota Gorontalo, Gorontalo 96128, Indonesia \\ E-mail: rio@ ung.ac.id ${ }^{1}$, tri.handayani.amaliah@ gmail.com ${ }^{2}$
}

\section{Article History:}

Received: 24-11-2021

Revised: 29-11-2021

Accepted: 30-11-2021
Keywords: Pencatatan, Pelaporan Keuangan UMKM

\begin{abstract}
:
Realitas rendahnya pemahaman UMKM di Desa Botubarani saat ini tentang pencatatan keuangan terhadap transaksi yang terjadi dalam aktivitas usahanya. Padahal seharusnya para pelaku UMKM menyadari faktor-faktor yang dapat mempengaruhi keberhasilan usahanya. Pelatihan ini dimaksudkan untuk membantu para pelaku UMKM di Desa Botubarani untuk memiliki kemampuan dan kesadaran dalam penyelenggaraan pencatatan keuangan bagi usaha yang tengah dijalankan dengan fokus menitikberatkan pada tujuan: 1) Meningkatkan pengetahuan dan pemahaman bagi pelaku UMKM tentang pentingnya pemanfaatan pencatatan akuntansi dalam mencapai keberhasilan usaha; 2) Meningkatkan kemampuan pelaku UMKM dalam melakukan pelaporan keuangan dengan baik dan benar. Peserta yang mengikuti pelatihan ini yaitu para pelaku UMKM di Desa Botubarani. Pelaksanaan pelatihan menggunakan metode praktik dalam hal teknis seperti pencatatan terhadap transaksi keuangan usaha UMKM dan pelaporan keuangan UMKM. Program pengabdian ini diharapkan dapat bermanfaat dalam pengembangan kompetensi pelaku UMKM di Desa Botubarani untuk menghasilkan informasi keuangan yang akurat dalam mengelola usahanya.
\end{abstract}

\section{Pendahuluan}

Berbicara tentang covid 19 saat ini merupakan topik yang menarik untuk dikaji. Bukan saja karena dampak yang ditimbulkan telah mampu meluluhlantahkan aktivitas sektor perekonomian namun juga sektor lainnya tanpa terkecuali. UMKM (Usaha Mikro Kecil dan Menengah) adalah merupakan pihak yang sangat terkena dampak covid 19 yang seolah tak berkesudahan terjadi saat ini. Realitas yang ada pertahanan UMKM berhasil diruntuhkan oleh wabah covid 19 yang tentunya berbeda pada saat krisis moneter yang pernah melanda Indonesia pada tahun 1998 silam. Tak sedikit para pelaku UMKM menjerit dalam ketidakberdayaan untuk mempertahankan usaha yang selama ini telah dirintis dan digeluti. Seperti diketahui bersama bahwa selama masa pandemi ini, aktivitas masyarakat khususnya pelaku UMKM di luar ruangan cenderung berkurang dan membuat pendapatan yang diperoleh jadi ikut merosot. Pelaku UMKM mulai merasa kesulitan dalam memenuhi kebutuhan operasional produksi karena omzet yang didapat tidak sesuai harapan. Daripada "gulung tikar" dalam usahanya kini pelaku UMKM seolah tak peduli adanya ancaman virus corona dengan tetap melakukan aktivitas berjualan produknya. 
Pandemi covid-19 yang masuk ke Indonesia sejak maret 2020 memang telah memorakporandakan perekonomian dunia, termasuk Indonesia. Melemahnya daya beli konsumen, penurunan tingkat investasi yang berujung pada penutupan usaha, serta turunnya harga komoditas merupakan beberapa dampak yang dihasilkan oleh pandemi covid-19 pada sektor ekonomi (Fiqri dan Junaedi, 2021). Ketiga dampak tersebut paling berat dirasakan oleh para pelaku usaha sehingga kreatif dan inovatif menjadi kunci utama bagi keberlangsungan usaha yang dijalankan, apalagi usaha tersebut masih tergolong Usaha Mikro Kecil dan Menengah (UMKM).

Terdapat beberapa faktor yang menyebabkan tersendatnya usaha para pelaku UMKM, diantaranya yaitu terbatasnya pengetahuan tentang pencatatan dan pelaporan keuangan khususnya di era pandemi covid 19 saat ini. Kondisi tersebut, disebabkan karena latar belakang pendidikan dan pengalaman yang dimiliki oleh para pelaku UMKM, dan hingga saat ini juga pelaku UMKM di Desa Botubarani belum pernah mengikuti pelatihan untuk menunjang kompetensi tersebut. Oleh karena itu, diperlukan peran serta dari perguruan tinggi dalam memberikan sharing ilmu terkait penguatan pengetahuan masyarakat pelaku UMKM, melalui fungsi tri dharma perguruan tinggi berupa pengabdian kepada masyarakat.

Terkait tentang UMKM, bila dilihat dari hasil sensus ekonomi tahun 2016, jumlah UMKM di Provinsi Gorontalo mencapai 157.000 usaha. Di Kota Gorontalo jumlah UMKM setiap tahunnya mengalami peningkatan setiap tahunnya. Berdasarkan data dari BPS Provinsi Gorontalo tahun 2019 sebanyak 10.817 UMKM, dan pada tahun 2020 UMKM berjumlah 11.640 usaha. Skala usaha mikro dan kecil masih mendominasi dunia usaha di Provinsi Gorontalo. Sebaran jumlah UMKM ini mengikuti sebaran jumlah penduduk. Dari kalngan penduduk kelas bawah dan menengah. Dengan jumlah UMKM yang ada, peran UMKM mampu berperan penting dalam berkontribusi dalam perekonomian bangsa, menciptakan lapangan pekerjaan, mendorong pertumbuhan ekonomi melalui Produk Domestik Bruto (PDB) serta mempercepat pemerataan pendapatan masyarakat. Hal ini sejalan dengan yang diungkapkan oleh Arifqi dan Junaedi (2021) bahwa UMKM menjadi tumpuan harapan pemulihan system perekonomian masyarakat. Sehingga kesulitan yang dialami di saat kondisi pandemi covid 19 saat ini usaha UMKM memberikan tantangan sekaligus peluang bagi perkembangan ekonomi bangsa.

Program pengabdian ini hadir guna membantu pelaku UMKM untuk meningkatkan kemampuan para pelaku UMKM dalam melakukan pencatatan dan pelaporan keuangan yang baik dan benar. Hal ini sangat berguna sebagai bekal bagi pelaku UMKM agar usaha yang dirintis akan dapat meraih kesuksesan secara berkelanjutan.

\section{Metode}

Khalayak sasaran dalam kegiatan penelitian ini adalah para pelaku UMKM di Desa Botubarani Kecamatan Kabila Bone. Beberapa kriteria usaha yang tergolong dalam UMKM menurut UU No 20 tahun 2008 adalah sebagai berikut :

1. Usaha mikro adalah usaha yang memiliki kekayaan bersih atau asset paling banyak Rp. 50.000.000. dan hasil penjualan atau omzet minimal adalah Rp.300.000.000 dalam setahun

2. Usaha kecil adalah usaha dengan kekayaan bersih atau asset yang mencapai Rp.50.000.000 tidak termasuk dengan harga tempat untuk mendirikan usaha. Hasil penjualan atau omzet yang dihasilkan oleh jenis usaha ini adalah sekitar Rp.300.000.000 sampai Rp.2.500.000.000. 
3. Usaha Menengah adalah usaha dengan total kekayaan bersih atau asset sebesar Rp.500.000.000 sampai Rp.10.000.000.000. jumlah omzet per tahunnya mulai Rp.2.500.000.000 sampai dengan Rp.50.000.000.000.

Metode yang digunakan dalam kegiatan pelatihan ini sebagai berikut:

1. Metode ceramah digunakan oleh pemateri untuk menjelaskan materi yang berkaitan dengan pencatatan dan pelaporan keuangan. Metode ceramah dilakukan di awal sebelum pelatihan sebagai pengantar untuk membuat pembukuan sederhana karena tidak semua pelaku usaha mikro adalah orang yang mengerti istilah-istilah dalam ekonomi/akuntansi. Sehingga dengan metode ini peserta pelatihan akan mendapatkan pengetahuan yang cukup dalam pengaplikasian pencatatan. Materi yang diberikan meliputi: pengertian pencatatan, manfaat pencatatan serta pelaporan keuangan.

2. Metode diskusi digunakan untuk memperdalam materi bahasan baik bentuk tanya jawab secara perorangan maupun perwakilan peserta.

3. Latihan digunakan dalam membuat pencatatan dan pelaporan. Dengan metode ini para pelaku UMKM diberikan contoh dalam mengisi jurnal atau buku catatan harian terkait penerimaan dan pengeluaran.

Kegiatan pengabdian ini untuk meningkatkan kompetensi serta pemahaman para pelaku UMKM dalam melakukan pencatatan dan pelaporan keuangan. Adapun rancangan evaluasi dalam kegiatan ini dilaksanakan dalam tiga tahap yakni:

1. Tahap perencanaan kegiatan. Pada awal kegiatan ini, pemateri menjelaskan tentang materi yang akan disampaikan.

2. Tahap selama proses kegiatan. Berdasarkan materi yang telah disampaikan peserta diberikan pelatihan dalam pencatatan dan pelaporan keuangan secara sederhana.

3. Tahap akhir kegiatan. Evaluasi pada akhir kegiatan ini dilakukan untuk mengukur keberhasilan dari seluruh program pelatihan ini. Pada tahap ini $85 \%$ peserta yang berasal dari masyarakat pelaku UMKM yang ikut serta dalam kegiatan pelatihan ini dapat melakukan pencatatan dan pelaporan keuangan usaha mereka.

\section{Hasil}

Pelatihan ini beranjak dari adanya realitas UMKM di Desa Botubarani saat ini. Rendahnya pemahaman terkait pencatatan keuangan terhadap transaksi yang terjadi dalam aktivitas usaha yang digeluti dimana tercatat hanya sebesar 3\% data UMKM di Provinsi Gorontalo yang melakukan pencatatan keuangan. Padahal dengan adanya pemahaman dan implementasi yang baik terhadap pencatatan dan pengelolaan keuangan dapat membantu para pelaku UMKM dalam pencapaian keberhasilan usaha UMKM. Pelatihan ini dimaksudkan untuk membantu para pelaku UMKM yang terdapat di Desa Botubarani untuk memiliki kemampuan dan kesadaran dalam penyelenggaraan pencatatan keuangan bagi usaha yang tengah dijalankan. Oleh karena itu pelatihan ini menitikberatkan pada peningkatan pengetahuan dan pemahaman bagi pelaku UMKM tentang pentingnya pemanfaatan pencatatan akuntansi dalam mencapai keberhasilan usaha serta berfokus pada peningkatan kemampuan pelaku UMKM dalam melakukan pelaporan keuangan dengan baik dan benar. 
Gambar 1. Pelaksanaan Kegiatan Pelatihan

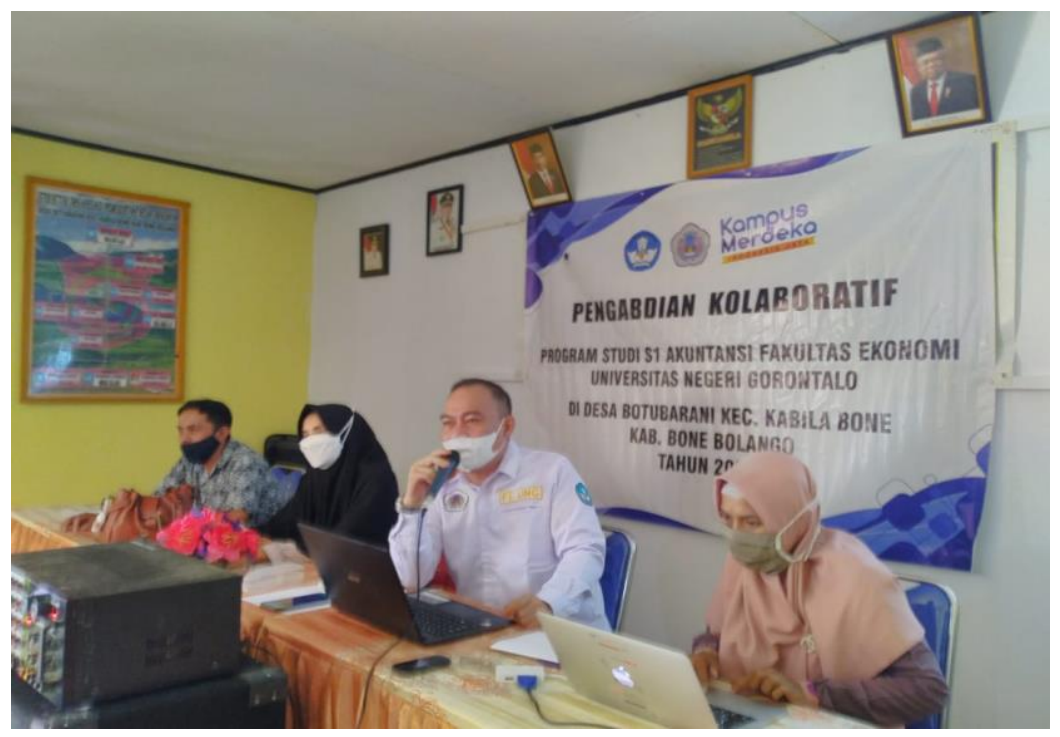

Dalam kegiatan pengabdian ini peserta yang mengikuti pelatihan terdiri dari para pelaku UMKM yang terdapat di Desa Botubarani. Adapun pelaksanaan pelatihan dilakukan dengan menggunakan metode praktik dalam hal teknis seperti pencatatan terhadap transaksi keuangan usaha UMKM dan pelaporan keuangan UMKM. Program pengabdian ini diharapkan dapat bermanfaat dalam pengembangan kompetensi pelaku UMKM di Desa Botubarani untuk menghasilkan informasi keuangan yang akurat dalam mengelola usahanya.

\section{Gambar 2. Peserta Kegiatan Pelatihan}
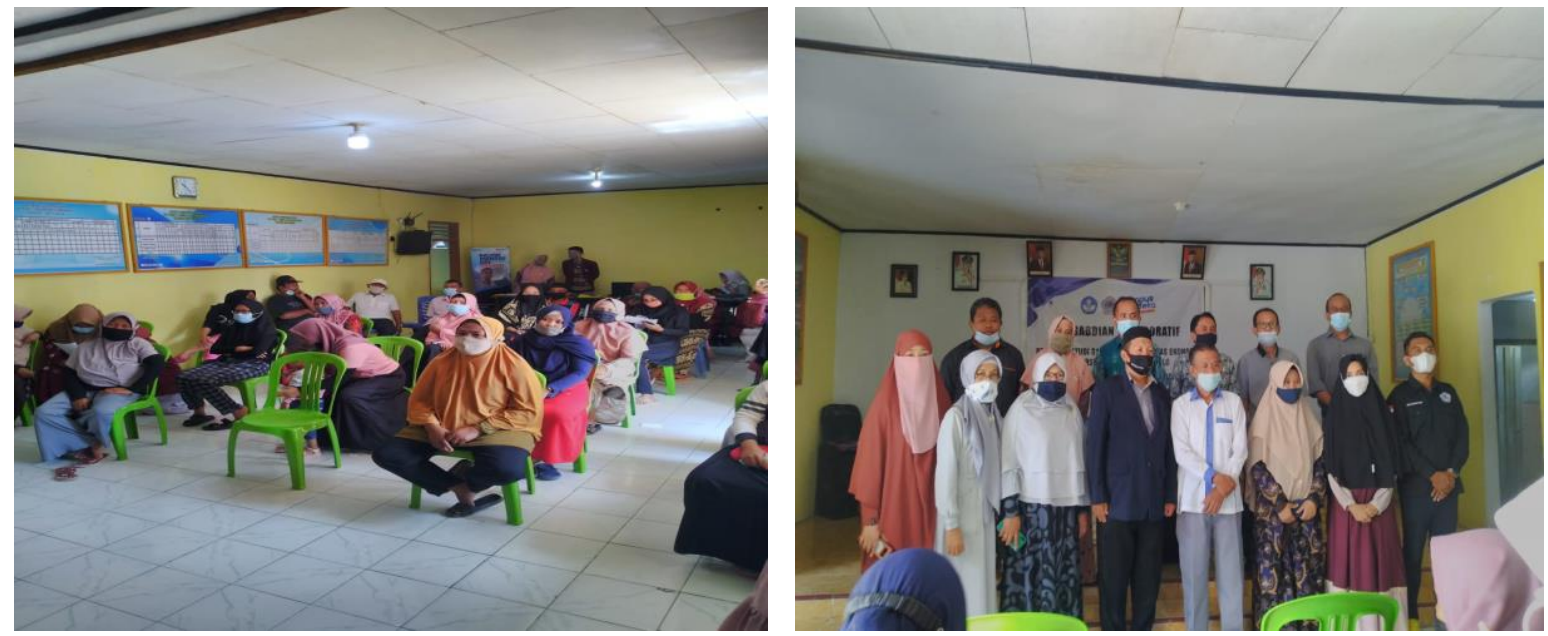

Berdasarkan hasil pengabdian langsung yang dilakukan, penulis menyimpulkan bahwa para pelaku UMKM cenderung belum memahami apa yang dimaksud dengan pencatatan dan pelaporan keuangan.

Ada beberapa jenis dari laporan keuangan, dimana setiap jenis memiliki tujuan dan fungsi yang berbeda-beda. Laporan keuangan untuk UMKM sendiri telah diatur dalam Standar Akuntansi Keuangan Entitas Mikro Kecil Menengah (SAK-EMKM). Dimana jenis-jenis laporan keuangan yang harus disusun oleh pelaku UMKM terdiri atas : 
1. Laporan Posisi Keuangan

Tujuan dari laporan posisi keuangan adalah untuk menyediakan informasi mengenai aset (kekayaan), kewajiban (kewajiban), dan asset netto serta informasi mengenai hubungan antara unsur-unsur tersebut pada periode tertentu.

2. Laporan Laba Rugi

Laporan laba rugi bertujuan untuk memberikan informasi mengenai pendapatan dan pengeluaran atau biaya-biaya yang terjadi dalam suatu periode.

3. Catatan Atas Laporan Keuangan

Catatan atas laporan keuangan masukkan informasi yang tidak tercantum dalam laporan posisi keuangan dan laporan laba rugi.

Penemuan awal penulis pada masyarakat pelaku UMKM di Desa Botubarani adalah mereka kurang memahami apa yang sebenarnya dimaksud dengan laporan keuangan, pencatatan dan pelaporan keuangan. Mereka hanya melakukan pembelian serta penjualan barang tanpa melakukan pencatatan dan pelaporan keuangan. Sehingga dalam hal ini, tim pengabdi mencoba menjelaskan serta memberikan contoh bagaimana melakukan pencatatan dan pelaporan keuangan bagi UMKM sesuai dengan standar yang mengatur hal tersebut yaitu SAK EMKM.

Dokumen yang digunakan para pelaku UMKM di Desa Botubarani masih belum memadai sebagai bukti penerimaan dan pengeluaran kas pada usaha mereka. Padahal bukti transaksi atau dokumen tersebut sangat penting dalam rangka pencatatan, penyusunan atau pelaporan keuangan usaha mereka.

\section{Diskusi}

SAK EMKM yang disahkan pada tanggal 24 Oktober 2016 menjelaskan bahwa tujuan dari laporan keuangan adalah untuk menyajikan informasi tentang posisi keuangan dan kinerja entitas yang bermanfaat bagi pengguna dalam pengambilan keputusan ekonomi. Pengguna dalam hal ini, seperti kreditor dan investor. Pada dasarnya, laporan keuangan menggambarkan tentang bentuk pertanggungjawaban atas pengelolaan sumber daya yang dipercayakan pihak manajemen. SAK EMKM diharapkan membantu suatu entitas dalam menyelenggarakan transisi dari pelaporan keuangan berbasis kas ke pelaporan keuangan berbasis akrual. SAK EMKM diharapkan dapat diimplementasikan dan berlaku efektif sejak 1 Januari 2018.

Pencatatan dan pengelolaan keuangan sangat penting diterapkan oleh suatu entitas tidak terkecuali oleh organisasi UMKM. Melalui pencatatan transaksi keuangan yang dilakukan, maka aktivitas bisnis setiap waktunya dapat terkontrol dengan baik. Berdasarkan informasi yang disajikan dalam pelaporan keuangan pihak pelaku UMKM dapat melakukan evaluasi terhadap biaya-biaya yang dikeluarkan dalam memperoleh keuntungan usaha. Melaui informasi yang disajikan dalam pelaporan keuangan, para pelaku UMKM dapat melakukan perencanaan keberlanjutan dan pengembangan bisnis yang sedang digeluti. Namun realitas yang terjadi pada UMKM yang terdapat di Desa Botubarani saat ini hanya sebesar 3\% data UMKM di Provinsi Gorontalo yang melakukan pencatatan keuangan. Padahal seharusnya para pelaku UMKM menyadari faktor-faktor yang dapat mempengaruhi keberhasilan usahanya. Melihat realitas tersebut memberikan petunjuk betapa pentingnya pelatihan pengelolaan keuangan dilakukan pada UMKM yang terdapat di Desa Botubarani.

Pelatihan ini merupakan perjalanan membawa misi untuk untuk membina dan memberdayakan masyarakat yang tergolong dalam kelompok UMKM yang terdapat di Desa 
Botubarani. Melalui pendidikan dan pelatihan teknis pencatatan dan pelaporan keuangan program ini, dapat mengaplikasikan pengetahuan dan keterampilan dosen dan mahasiswa untuk memberikan solusi pemecahan terhadap masalah yang dihadapi oleh masyarakat terkait pencatatan dan pelaporan keuangan bagi UMKM. Selain itu kegiatan pengabdian diharapkan bisa menjadi pembelajaran bagi mahasiswa untuk dapat bekerja sama dan mengaplikasikan ilmu pengetahuan yang dimilikinya kepada masyarakat. Program ini difokuskan pada transfer pengetahuan bagaimana teknis pencatatan dan pelaporan keuangan UMKM sehingga diharapkan pada masa yang akan datang melalui kegiatan ini dapat menghasilkan "keluaran" dan outcome sesuai yang dicita-citakan bagi peningkatan taraf hidup masyarakat. Sejalan dengan itu, Linawati (2020) mengungkapkan bahwa pelatihan pengelolaan serta penyusunan laporan keuangan adalah kegiatan yang bermanfaat bagi peningkatan pengetahuan serta kemampuan pelaku usaha untuk mengelola modal yang dimiliki dengan baik. Sementara itu, Amaliah, Mattoasi dan Bokingo (2020) menyatakan bahwa kegiatan pelatihan pengelolaan keuangan dapat menjembatani kepentingan masyarakat agar memiliki kreativitas dan keahlian yang dapat memberikan kontribusi bagi keberlangsungan dan kesejahteraan mereka.

\section{Kesimpulan}

Berdasarkan pada rangkaian kegiatan pelatihan ini, maka dapat disimpulkan bahwa pencatatan dan pelaporan keuangan yang baik dan akurat dalam sebuah usaha tentu menjadi nilai tambah bagi usaha tersebut. Output yang dihasilkan dari kegiatan pencatatan yaitu laporan keuangan sendiri memiliki fungsi yang sangat penting yaitu memberikan informasi-informasi penting bagi kelangsungan hidup sebuah usaha. Dengan adanya laporan keuangan pihak pemilik usaha akan mampu menentukan langkah yang tepat dalam mengembangkan usahanya. Keputusan bisnis yang rasional akan mampu diambil oleh pelaku usaha apabila tersedia informasi yang cukup memadai, selain itu laporan keuangan juga menjadi bahan evaluasi agar dapat diketahui bagaimana kinerja usaha tersebut pada suatu periode tertentu. Untuk itu, catatan serta laporan keuangan memegang peranan yang penting dalam rangka pencapaian tujuan sebuah usaha.

Penulis menyarankan bagi para pelaku UMKM di Desa Botubarani untuk dapat melakukan pencatatan serta pelaporan sebagaimana yang telah diatur dalam Standar Akuntansi Keuangan Entitas Mikro Kecil Menengah (SAK EMKM) yang telah disampaikan dalam kegiatan pengabdian. Hal ini bertujuan untuk dapat meningkatkan efektivitas dari usaha yang dijalankan. Dengan terciptanya sistem pencatatan dan pelaporan yang baik maka peluang bagi para pelaku UMKM untuk melakukan pengembangan usahanya lebih besar, karena dengan adanya laporan keuangan yang terstandar, akan lebih mudah bagi pelaku UMKM untuk mendapatkan akses permodalan dari pihak ketiga.

\section{Pengakuan/Acknowledgements}

Ucapan terima kasih yang tak terhingga disampaikan kepada LPPM Universitas Negeri Gorontalo yang telah memfasilitasi kegiatan ini. Pemerintah Desa Botubarani dan peserta yakni para pelaku UMKM di Desa Botubarani atas kesempatan, waktu, dan perhatian yang luar biasa yang diberikan kepada kami tim pengabdi dapat melaksanakan kegiatan ini dengan baik. Kedepan diharapkan kegiatan pengabdian kepada masyarakat ini terus berkelanjutan. 


\section{Daftar Referensi}

Amaliah, T. H, Mattoasi, Bokingo, A., 2019. Pengembangan Social Enterpreneurship Berbasis Budaya Lokal Menuju Kemandirian pada Panti Asuhan Al Amanah Gorontalo. Jurnal Ilmiah Pangabdhi, Vol.5, No.2

Fikri, Chairul. 2021. Berita Satu. https://www.beritasatu.com/ekonomi/728997/tiga-dampakpandemi-covid19-bagi-perekonomian-nasional [Diakses pada 23 Mei 2021].

Hakim, M. S. \& Kunaifi, A. 2018. Peningkatan Kapabilitas Pengelolaan Keuangan UMKM Bidang Otomotif Melalui Pelatihan Pengelolaan Keuangan. SEWAGATI, Jurnal Pengabdian kepada Masyarakat, II(2), Hal. 102-104.

Linawati. (2020). Pelatihan Akuntansi dan Pengelolaan KeuanganBagi Wirausah Baru Kabupaten Nganjuk. Prosiding Seminar Nasional Abdimas Ma Chung, 203-211.

SAK EMKM. (2016). Standar Akuntansi Keuangan Entitas Mikro Kecil, Mikro \& Menengah. Ikatan Akuntan Indonesia.

Sukmadilaga, C., Sudrajat, Khasanah, U., Lestari, T. U., Devi, M. C., \& Ardian. (2018). Pelatihan Penyusunan Laporan Keuangan untuk Start Up Company Binaan Digital Lounge (DILO) PT. Telkom Bandung. Jurnal Aplikasi Ipteks Untuk Masyarakat, 3(7), 209-212.

Sulistyowati, Y. (2017). Pencatatan Pelaporan Keuangan UMKM (Study Kasus Di Kota Malang). Referensi: Jurnal Ilmu Manajemen Dan Akuntansi, 5(2), 49. https://doi.org/10.33366/ref.v5i2.831

Undang Undang Usaha Mikro, Kecil, dan Menengah, Pub. L. No. 20 (2008). 